\title{
Does training trigger turnover...or not? : the impact of formal training on young men's and women's job search behaviour
}

Citation for published version (APA):

Sieben, I. J. P. (2005). Does training trigger turnover...or not? : the impact of formal training on young men's and women's job search behaviour. Researchcentrum voor Onderwijs en Arbeidsmarkt, Faculteit der Economische Wetenschappen. ROA Research Memoranda No. 6E https://doi.org/10.26481/umaror.200506E

Document status and date:

Published: 01/01/2005

DOI:

10.26481/umaror.200506E

Document Version:

Publisher's PDF, also known as Version of record

Please check the document version of this publication:

- A submitted manuscript is the version of the article upon submission and before peer-review. There can be important differences between the submitted version and the official published version of record.

People interested in the research are advised to contact the author for the final version of the publication, or visit the DOI to the publisher's website.

- The final author version and the galley proof are versions of the publication after peer review.

- The final published version features the final layout of the paper including the volume, issue and page numbers.

Link to publication

\footnotetext{
General rights rights.

- You may freely distribute the URL identifying the publication in the public portal. please follow below link for the End User Agreement:

www.umlib.nl/taverne-license

Take down policy

If you believe that this document breaches copyright please contact us at:

repository@maastrichtuniversity.nl

providing details and we will investigate your claim.
}

Copyright and moral rights for the publications made accessible in the public portal are retained by the authors and/or other copyright owners and it is a condition of accessing publications that users recognise and abide by the legal requirements associated with these

- Users may download and print one copy of any publication from the public portal for the purpose of private study or research.

- You may not further distribute the material or use it for any profit-making activity or commercial gain

If the publication is distributed under the terms of Article $25 \mathrm{fa}$ of the Dutch Copyright Act, indicated by the "Taverne" license above, 


\section{Does Training Trigger Turnover...Or Not? The Impact of Formal Training on Young Men's and Women's Job Search Behaviour}

ROA-RM-2005/6E

Inge Sieben

Research Centre for Education and the Labour Market

Faculty of Economics and Business Administration Maastricht University

Maastricht, July 2005 
ISBN 90-5321-418-6

Sec05.064.doc 


\section{Contents}

Abstract

Acknowledgement

1 Introduction 1

2 Two Theoretical Perspectives 2

3 Data and Methods 9

4 Results 14

5 Conclusions and Discussion 19

References 



\begin{abstract}
This study advances on previous research on training and turnover in two ways. First, insights from the human capital perspective are contrasted with insights from the commitment perspective. Second, several aspects of training are simultaneously studied in one model: training incidence, duration, specificity, location, costs, time, and objectives. Using survey data from the 'Higher Education and Graduate Employment in Europe' project, I find that, in line with the human capital perspective, specific training decreases the probability to search for a new job. Moreover, it seems that training not provided by the employer and not followed during working hours induces more job search behaviour, at least for men. This could be interpreted as a negative version of the commitment perspective. After controlling for training specificity, training location, costs, and time no longer influence job search behaviour, however.
\end{abstract}

\title{
Acknowledgement
}

I would like to thank Ben Kriechel, Jasper van Loo, Maarten Wolbers, and participants of the ISA RC28 conference on "Welfare States and Social Inequality" in Oslo, May 5-8, 2005, for useful comments on an earlier version of this paper. 



\section{Introduction}

As the world is moving towards a knowledge economy, human capital is becoming increasingly important in comparison with traditional production factors such as capital and natural resources. Since a significant amount of schooling occurs after labour market entry, training is of immense value for both employees and employers. In general, training makes workers perform better in their jobs (Bartel, 1995). First of all, training is a way to bridge gaps between skills acquired during initial education and skills required at the job (De Grip, Heijke, \& Willems, 1998). Secondly, as acquired skills become outdated as a result of technological and organisational change, training is an instrument to prevent skills obsolescence (Bishop, 1997). Finally, training might increase workers' employability. Trained workers are more versatile in their job (Groot \& Maassen van den Brink, 2000), which increases their career opportunities both inside and outside the firm.

All this implies that job training is important for one's occupational career. Sociological research to date has predominantly focused on the effects of training on status attainment. It has been shown that education obtained during work life increases occupational prestige and improves employment conditions (for an overview of these studies, see $\mathrm{Li}$, König, Buchmann, \& Sacchi, 2000). Far less attention has been paid to the impact of training on job mobility. It is a shortcoming that this topic has not had a prominent place on the research agenda so far, for the preference to train is the joint outcome of a decision made by both the employee and the employer (Green, 1993). When evaluating the costs and benefits of training, workers and firms keep in mind the expected investment horizon, i.e. worker's turnover probability (Royalty, 1996). This makes it interesting to analyse whether training triggers turnover.

The vast majority of research on the relationship between training and turnover is done by economists, who adopt the human capital perspective. Training is seen as an investment that increases worker productivity. In the case of generating specific skills, training will lead to less job mobility, whereas general training usually will not have an effect on the employee's inclination to quit (cf. Becker, 1962). In this study, I will contrast these human capital insights with another, less common perspective, which is mostly found in psychological and human resource management (HRM) literature. This second perspective refers to training as a way to increase the organisational commitment of workers (Smith \& Hayton, 1999), thereby reducing their inclination to search for another job. By comparing both perspectives, a more comprehensive understanding of the relationship between training and job mobility is gained. This process is reinforced by taking different aspects of training into account. Both the human capital perspective and the commitment perspective make different predictions about the level of turnover depending on the type of training. So far, researchers have typically focused on one aspect of training only, like training incidence (e.g. Gritz, 1993), or on-the-job versus off-the-job training (e.g. Lynch, 1991). In this study, I will provide a more complete picture of the relationship between training and turnover by 
including several aspects of training in one model: training incidence, duration, specificity, location, costs, time, and objectives. ${ }^{1}$

In short, this study examines the impact of different aspects of formal training participation on job search behaviour of young men and women in the Netherlands. The focus is on job search instead of on actual turnover, because the latter is a composite of voluntary quits and involuntary layoffs (Zweimüller \& Winter-Ebmer, 2000). When studying the relationship between training and turnover, the primary interest is in voluntary quits. Since workers' intentions to quit are more strongly reflected in their job search behaviour, this probably is a better indicator for voluntary quits. Moreover, although job search will not necessarily induce job mobility, or, the other way around, job mobility will not always be preceded by job search, research generally finds a moderate relationship between the two (e.g. for the Netherlands, De Graaf \& Luijkx, 1997). Furthermore, determinants of the intention to change jobs are found to be prime determinants of actual turnover rates as well (Weisberg \& Kirschenbaum, 1991).

Given that workers often switch jobs when they are in the first years of their careers (Rosenfeld, 1992), and that they receive more training during this period than later in their work lives (Green, 1993), I focus on young workers. Moreover, I study higher educated workers, i.e. graduates from higher vocational college or university. Higher educated workers receive more training (Altonji \& Spletzer, 1991) and are more mobile (Carroll \& Mayer, 1986) than lower educated workers. Finally, I pay attention to differences between male and female workers, since training and career patterns of women are quite different from those of men.

\section{Two Theoretical Perspectives}

\section{Human Capital Perspective}

The vast majority of studies on training and turnover are based on economic insights and take the human capital perspective as a starting point. In this perspective, training is seen as an investment that increases worker productivity. In his seminal article on human capital,

1. Like almost all studies on training and turnover, the focus of this study is on formal job training. Formal job training is defined as formally organized training activities, such as training programs (cf. Mincer, 1962). Most job training, however, is informal (Bishop, 1997). Although there also are problems with the measurement of formal training (Bartel, 1995), informal training, like observing coworkers, learning-by-doing, and speaking with supervisors, is very difficult to measure (Veum, 1995). Some researchers, therefore, use tenure as a proxy for informal training (e.g. Groot \& Maassen van den Brink, 2000), but as Dolton and Kidd (1998) point out, this proxy is poor since the level of skill acquisition is largely determined by the type of job held. Wholey (1990), who measures the degree of both formal and informal training in a direct way, finds that formal job training determines employee mobility to a higher extent than informal training. 
Becker (1962) distinguishes between two types of training: general and specific. ${ }^{2}$ General training is equally useful in many firms: it raises worker's productivity at other employers by the same amount as at the employer that provides the training. Because workers can take their acquired transferable skills to other employers, general training is a risk for the employer providing it. This risk is often referred to as the poaching or "cherry-picking" problem: other firms may hire trained workers away (Lynch \& Black, 1998). This risk makes that employers stimulate participation in general training only when they do not have to pay the associated costs. Becker (1962) argues that employees are willing to pay the general training costs themselves since this kind of training benefits them by increasing their future wages. Specific training on the other hand, is defined as training that only increases worker's productivity at the employer providing the training. Because workers cannot use the acquired skills in other firms, there will be no increase in future wages. ${ }^{3}$ Employees are not willing to pay for specific training costs, unless there is a contract between employers and employees to share the benefits. In such a case, wages will increase but not to the same extent as the rise in productivity (Green, Felstead, Mayhew, \& Pack, 2000). However, if such a contract does not exist, the employer will have to pay the costs for specific training programs.

According to Becker (1962), turnover becomes an issue when costs are imposed on firms or workers, as is the case with specific training. Since the benefits to specific training are lost when a worker leaves the firm, employees would be rather reluctant to start looking for a new job and employers would be rather reluctant to fire a worker. This means that specific training should unambiguously be associated with lower turnover rates (Loewenstein \& Spletzer, 1999). However, in the case of general training, there is no reason to expect a consistent effect on the employees' inclination to quit (Stromback, 2002).

Although the human capital perspective is dominant in research on training and turnover, it is not without flaws. Several authors have argued that the original human capital model is based on rather strong assumptions (e.g. Eckaus, 1963; Acemoglu \& Pischke, 1999). In more realistic, imperfect labour markets - like markets with a limited number of firms (Booth, 1991) or with imperfect information on workers' skills (Katz \& Ziderman, 1990) - employers would be willing to bear (part of) the costs for general training. Since they do not want to lose their investments, firms paying for general training will have an incentive to reduce their turnover rates. A second, more fundamental criticism of the human capital perspective is that individuals are not rationalist egoists, but act upon group loyalties and obligations as well (Fevre, Rees, \& Gorard, 1999). These arguments lead us to consider a second theoretical perspective, mostly found in psychological and HRM literature: the commitment perspective.

2. Some researchers have argued that the distinction between general and specific training is too strict to account for reality. For example, Stevens (1999) distinguishes a third type of training, transferable training, which is productive in some, but not all firms. Lazear (2003) proposes a skillweights approach in which all training is general in the sense that other firms use the skills acquired by training. However, firms use these skills in different combinations and with different weights attached to them.

3. This holds for future wages outside the firm. Within the firm, an increase in wages can be expected because of increased productivity. 


\section{Commitment Perspective}

The relationship between training and turnover can also be viewed from the perspective of organisational commitment (Smith \& Hayton, 1999). Training that generates commitment of employees to their employer will reduce turnover, since more committed employees will be less inclined to start looking for a new job. But how does training generate organisational commitment? First of all, employers that train signal that they are 'investors in people'. Employees consider these employers attractive to work for, because training not only improves workers' employability and career opportunities (Groot \& Maassen van den Brink, 2000), but also meets workers' intrinsic motivation to learn (Noe, \& Wilk, 1993). Thus, workers will be more inclined to stay employed in a firm that offers attractive training opportunities.

In addition, employees may interpret training as a signal of the employer about the nature of their relationship (Tannenbaum, Mathieu, Salas, \& Cannon-Bowers, 1991; Barrett \& O'Connell, 2001). Trained workers will have the impression that their employer sees them as important members of the organisation, which will generate loyalty to the firm. Or, put in other words, employees may view training as an indication that the firm is willing to invest in them and cares about them. Since they feel valued, they will be less inclined to quit. This will particularly hold when training is perceived as a gift, as is the case when the employer provides general training (Barrett \& O'Connell, 2001).

Taking this into account, it is interesting to note that some formal training indeed has the direct objective of raising organisational commitment, as Green et al. (2000) show. They also observe that training programmes may be combined with other human resource practices that generate commitment to the employer, like mentoring, appraisal programmes, and employee involvement schemes. Heyes and Stuart (1996) find that employees' commitment to the firm increases when there is a structured, formalised approach to training which explicitly links skills formation to job tenure and reward.

All this implies that training will reduce workers' intentions to look for another job, because it creates organisational commitment. However, the amount of organisational commitment generated through training will depend on the type of training. This makes it important to distinguish between different aspects of training participation.

\section{Different Aspects of Training}

A major drawback of studies on training and turnover to date is that they usually consider one aspect of training only, such as training incidence (e.g. Gritz, 1993; De Grip, Heijke, \& Willems, 1998; Krueger \& Rouse, 1998), on-the-job versus off-the-job training (e.g. Lynch, 1991; Royalty, 1996; Parent, 1999), or employer-provided versus self-financed training (e.g. Zweimüller \& Winter-Ebmer, 2000). Exceptions are the study by Green et al. (2000), which brings in training sponsorship, skill transferability as well as training objectives, and the study by De Wolff, Luijkx, and Kerkhofs (2003) in which training location, funding, and type of 
training are included. ${ }^{4}$ In this study, I will provide a more comprehensive account of the relationship between formal training and job search behaviour by studying as many aspects of training as possible. I will look at training incidence, duration, specificity, location, payment, time, and objectives. In doing so, the different insights of the human capital and the commitment perspective are useful. As will become clear, the two theoretical perspectives often lead to opposing hypotheses on the relationship between different aspects of formal training and job search behaviour.

Training incidence. According to the human capital perspective, training itself will not have an impact on employees' job search behaviour, as it is specific training only that will make workers less inclined to quit their job. The commitment perspective, however, predicts that training - both general and specific - will increase the organisational commitment of workers and, therefore, decrease their job search behaviour. Previous studies on the relationship between training incidence and turnover show mixed results. Green et al. (2000) find that training, on average, has no impact on job search, whereas De Wolff, Luijkx, and Kerkhofs (2003) observe that training participation leads to more job search. Elias (1994) shows that women who followed formal training have a lower probability of quitting their job, but no such effect is found for men.

Training duration. The amount of hours spent on training can be seen as an indicator for training intensity. The human capital perspective does not make any predictions on the effect of training duration on job search, as longer lasting types of training are found to be no more specific than shorter programs (Veum, 1997). However, from the commitment perspective, more intensive training will reduce job search, as such training will generate more commitment to the firm. Previous research shows that an increase in the number of training days indeed increases the probability of staying in the same job (Dolton \& Kidd, 1998). De Wolff, Luijkx, and Kerkhofs (2003), however, do not find an effect of training duration on either job search or mobility.

Training specificity. The human capital perspective places great emphasis on the specificity of training. It predicts that specific training will decrease workers' inclination to quit, whereas general training does generally not affect turnover. To put these hypotheses to the test, two types of specific training are distinguished in this study: specific training in one's own field of study and specific training in another field. As the first can be considered to be more specific than the latter, I predict in line with the human capital perspective that specific training in one's own field will affect job search more adversely than specific training in another field. General training is split up in two types as well: overall general training and management training. According to the human capital perspective, general training will not affect job search. The commitment perspective takes a different view on this. Employees will perceive general training more as a gift than specific training, because they realise that general training is useful outside the employing firm as well (Barrett \& O'Connell, 2001). General training thus causes workers to be more committed to the firm and less inclined to quit. This holds even more for management training, as this type of training can be interpreted as a

4. Both studies, however, do not present separate analyses for male and female workers. 
clear signal of the employer that (s)he values the worker and is prepared to invest in her or him. Furthermore, employees who were involved in specific training in their own field of study will have the lowest probability of searching for a new job, for this kind of specific training can be perceived as being less of a gift than specific training in another field, as it is less useful outside the firm than the latter. Empirical research with direct measures on the specificity of training is very scarce. An exception is the study of Green et al. (2000), which looks at the transferability of skills developed by the training. In line with the predictions of the human capital perspective, they find that specific training, compared to general training, substantially reduces job search.

Training location. In the absence of direct measures on the specificity of training, researchers often look at the distinction between on-the-job versus off-the-job training. Onthe-job or in-company training is considered to be more specific in nature than off-the-job training (Lynch, 1991). From a human capital perspective, this implies that employees who receive on-the-job training are less likely to quit, whereas employees involved in off-the-job training are not affected in their mobility behaviour. The commitment perspective, on the other hand, predicts that off-the-job training decreases the probability to leave, since this kind of training might be perceived more as a gift than on-the-job training. The human capital perspective is corroborated by several studies, like Lynch (1992b), Loewenstein and Spletzer (1997 and 1999), Stromback (2002), and De Wolff, Luijkx, and Kerkhofs (2003). Others, however, observe that off-the-job training increases the probability of leaving (Veum, 1997), a finding that appears to be even stronger for women (Lynch, 1991 and 1993).

Training payment. Training costs include tuition fees, books, and relocation costs (Bennett, Glennerster, \& Nevison, 1992). The human capital perspective predicts that employers pay for specific training only. As specific training is related to lower levels of turnover, employerprovided training will reduce workers' likelihood to search for a new job. Self-financed training is, on the other hand, associated with general training, and will, therefore, have no effect on job search. The commitment perspective, however, stresses that training paid for by the employer will be perceived as a gift. Employees will feel appreciated and esteemed by the employer and will therefore be less inclined to leave. In line with the predictions of the commitment perspective, Veum (1997) finds that employer-provided training decreases worker's job search activities, whereas non-employer financed training increases the probability of job search. Zweimüller and Winter-Ebmer (2000) corroborate this result for men and women separately. De Wolff, Luijkx, and Kerkhofs (2003), however, find no effect of employer-provided training on search behaviour.

Training time. In addition to the direct costs associated with training, opportunity costs arise, such as forgone productivity, or leisure time of the employee participating in training (Stevens, 1999). When training takes place during working hours, the employer bears the opportunity costs. The human capital perspective predicts that this occurs only in the case of specific training. Therefore, workers who follow training during working hours will be less inclined to quit. Training followed during leisure time will, however, not affect employees' job search behaviour, as it is assumed to generate general skills. The commitment perspective suggests that training followed during working hours is perceived as a gift from the employer. 6 
This kind of training increases employees' organisational commitment and decreases their job search activities. The only study on training and turnover that takes training time into account is by Green et al. (2000). Training during working hours is, however, combined with information on who paid for the training fees and on whether or not wages were reduced during training into a typology of training sponsorship. It is found that when training is entirely sponsored by the employer, the likelihood of job search decreases. Training entirely sponsored by the employee significantly increases the probability to quit.

Training objectives. Finally, training can be followed for different reasons. Bartel (1995) for example, distinguishes between core training and employee development training. The first kind of training has the objective to improve qualifications and skills for the current occupation. Workers will follow this training in order to keep up with current job requirements that change because of technological and organisational developments. Since this kind of occupational updating often is specific in its nature, it will decrease the probability of job search according to the human capital perspective. Employee development training, on the other hand, is more general. It prepares workers for the next steps in their careers and will, therefore, be labelled career training. The human capital perspective predicts no direct effect of career training on job search behaviour. Next to occupational updating and career training, I distinguish a third training objective: retraining for a new occupation. ${ }^{5}$ From a human capital point of view, the switch to a new occupation implies depreciation of initially invested human capital ( $\mathrm{Li}$ et al., 2000). Workers will be interested in retraining when it corrects a wrong investment decision in the past. When employees participate in retraining, they will, thus, be more inclined to search for a new job. From the commitment point of view, it can be argued that both career training and retraining will be more perceived as a gift of the employer than occupational updating. Workers involved in career training and retraining will therefore be more committed to the organisation and less inclined to quit. Previous research, however, observes a positive effect of career training on job mobility (Dekker, De Grip, \& Heijke, 2002). Retraining is found to positively affect mobility too, but for women only (Li et al., 2000). Finally, occupational updating has no significant effect on job mobility (Li et al., 2000; Dekker, De Grip, \& Heijke, 2002).

To sum up, the human capital perspective and the commitment perspective make different predictions about the effects of several aspects of formal job training on job search behaviour. Table 1 gives an overview of these predictions in the shape of testable hypotheses. The results of the empirical analyses will show which perspective is the most promising in explaining the relationship between training and turnover.

5. Another training objective may be found in training aimed at a higher or second credential ( $\mathrm{Li}$ et al., 2000). This so-called advanced training often facilitates entry into high-status occupations. Since I focus on workers who graduated from tertiary education (i.e. vocational college or university), I don't think this distinction is a very interesting one here. Moreover, the dataset I employ does not contain any information on training credentials. 
Table 1

Overview of hypotheses on the relationship between several aspects of formal training and job search behaviour derived from the human capital perspective and the commitment perspective

\begin{tabular}{|c|c|c|}
\hline Training aspect & Human capital perspective & Commitment perspective \\
\hline Incidence & No effect of training on job search & $\begin{array}{l}\text { Training induces less job search than no } \\
\text { training }\end{array}$ \\
\hline Duration & $\begin{array}{l}\text { No effect of training duration on job } \\
\text { search }\end{array}$ & $\begin{array}{l}\text { Longer training induces less job search } \\
\text { than shorter training }\end{array}$ \\
\hline Specificity & $\begin{array}{l}\text { Specific training induces less job } \\
\text { search, especially when in own field; no } \\
\text { effect of overall general training and } \\
\text { management training on job search; }\end{array}$ & $\begin{array}{l}\text { Management training and to a lesser } \\
\text { extent overall general training induce } \\
\text { less job search than specific training in } \\
\text { another field and in own field }\end{array}$ \\
\hline Location & $\begin{array}{l}\text { On-the-job training induces less job } \\
\text { search; no effect of off-the-job training } \\
\text { on job search }\end{array}$ & $\begin{array}{l}\text { Off-the-job training induces less job } \\
\text { search than on-the-job training }\end{array}$ \\
\hline Payment & $\begin{array}{l}\text { Training paid by employer induces less } \\
\text { job search; no effect of self-financed } \\
\text { training on job search }\end{array}$ & $\begin{array}{l}\text { Training paid by employer induces less } \\
\text { job search than self-financed training }\end{array}$ \\
\hline Time & $\begin{array}{l}\text { Training during working hours induces } \\
\text { less job search; no effect of training } \\
\text { during leisure time on job search }\end{array}$ & $\begin{array}{l}\text { Training during working hours induces } \\
\text { less job search than training during } \\
\text { leisure time }\end{array}$ \\
\hline Objectives & $\begin{array}{l}\text { Occupational updating induces less job } \\
\text { search; retraining induces more job } \\
\text { search; no effect of career training on } \\
\text { job search }\end{array}$ & $\begin{array}{l}\text { Career training and retraining induce } \\
\text { less job search than occupational } \\
\text { updating }\end{array}$ \\
\hline
\end{tabular}

\section{Gender Differences}

Some of the empirical studies mentioned above find significantly different effects of formal training on job search behaviour for men and women (e.g. Wholey, 1990; Lynch, 1993; Li et al., 2000). This implies that the mechanisms behind these effects work in different ways for women and for men. One of the reasons is that the occupational careers of men and women vary substantially, although differences might be less pronounced for the higher educated. Still, due to family obligations, women have more interrupted careers or work more in parttime jobs than men. This is especially the case in the Netherlands, which has been labelled as "the only part-time economy in the world" (Freeman, 1998:2). Both interrupting the employment career and working part-time are thought to have negative consequences for further career development. ${ }^{6}$ In addition, some studies find that women are more mobile

6. Wolf and Rosenfeld (1978), however, show that interrupting the employment career is not so detrimental for women if they are working in so-called women's occupations, which are characterised by limited chances for advancement. 
than men (Carroll \& Mayer, 1986), whereas others show that men are much more likely to change employers than women (Lynch, 1993).

Moreover, men and women display different training patterns. A vast body of research shows that female workers follow less training than male workers (e.g. Altonji \& Spletzer, 1991; Bishop, 1997; Arulampalam \& Booth, 1998). This finding is generally explained as a result of women being less willing to participate in training due to lower returns of investment - as mentioned above, many women have interrupted careers or work part-time - or as a result of statistical discrimination by employers (cf. De Grip, Heijke, \& Willems, 1998). Lynch (1992a) in a more refined analysis finds that men receive more on-the-job training than women, but women receive slightly more off-the-job training. In addition, Booth (1991) shows that while men receive more formal training than women, the average number of days spent in training is larger for women than for men.

Since both training and career patterns differ for men and women, it is important to examine the effects of formal training on job search behaviour for male and female workers separately.

\section{Data and Methods}

To test the hypotheses, I employ data collected for the project 'Higher Education and Graduate Employment in Europe.' ${ }^{7}$ The data for the Netherlands consist of a representative sample of Dutch men and women graduating from tertiary education (i.e. colleges for higher vocational education or universities) in the academic year 1990-1991. At the end of 1998, about 6,000 graduates were approached, of which 2,723 responded with a completed questionnaire. This means that I have information on Dutch workers who have been on the labour market for eight years at the most. The analyses are restricted to graduates who at the time of survey were between 27 and 40 years of age and in paid employment for at least 12 hours per week. ${ }^{8}$ After removing missing observations on the variables used, these selections leave me with 658 men and 621 women for the analyses.

Table 2 gives an overview of the variables included in the analyses. The dependent variable, job search behaviour, is measured by asking respondents: "Did you actively look for another paid job in the last four weeks?". 19 per cent of the men and women in the dataset answered "yes" to this question. With respect to the training variables, respondents could first indicate

7. This project was partially funded by the European Commission in the Targeted Socio-Economic Research program (TSER EGS-SOE2-CT97-2023), with additional funding by the Dutch Ministry of Education.

8. 609 respondents did not meet the age restriction; an additional 38 respondents were not in paid employment of at least 12 hours a week. Self-employed workers and freelancers $(n=180)$ are excluded from the analyses as well, since their training and career patterns are different from workers in paid employment (Form, 1982). 
whether or not they followed job training. ${ }^{9}$ In line with the findings of previous research, more male than female workers participate in training: 54 per cent and 49 per cent respectively. Respondents could then mention up to three courses followed, and were subsequently asked to select the most important one in terms of their work and career. All other training variables pertain to this selected training event. Training duration is measured by multiplying the number of training weeks by the (average) number of training hours per week. Because the relationship between training duration and job search turned out to be non-linear, I use five categories in the analyses. Previous research shows that most formal training received by workers is of a rather short duration (Lynch, 1993). This is in line with the results found here. I observe that job training on average lasts 138 hours for men and 106 hours for women (excluding those who do not follow training). Thus, when participating in training, women do not spend more hours in training then men, as Booth (1991) shows. Training specificity is constructed by combining the responses to two questions. First, respondents could tick the subjects the training dealt with. Training in oral and written communication skills is considered to be overall general training, whereas training in understanding management practices or training in supervising skills is viewed as management training. In addition, training courses are coded in fields of study according to the description the respondents gave. If the training is in the same field as the tertiary education of the respondent, it is labelled specific training in one's own field of study; otherwise it is called specific training in another field. Women participate somewhat more in overall general training and in specific training in their own field, whereas men more often take management training. On-the-job training is defined as company training. Most respondents, however, participate in off-the-job training: 42 per cent of men and 38 per cent of women followed training on a location outside the firm. Employers usually completely pay the direct costs of training. Only in a few cases (about 5 per cent of the respondents), training costs are paid by the employee, the government, or in another way. 30 per cent of men and 26 per cent of women participate in training followed entirely during working hours, which means that employers also bear the opportunity costs of training in many cases. Women, however, appear to follow training during leisure time more often than men do. Finally, three training objectives are distinguished: to improve qualifications and skills for the current occupation (occupational updating), to advance in one's career (career training), and to prepare for a new occupation (retraining). Men participate more in career training ${ }^{10}$, whereas women more often follow training related to occupational updating.

9. Formal initial education and hobby courses were explicitly excluded in the wording of the survey question.

10. Career training (training objective) is only moderately correlated with management training (training specificity): $r=.427$ for men and $r=.342$ for women. 
Table 2

Descriptives of variables

Men $(n=658)$

$\%$

Women $(n=621)$

$\%$

Dependent variable

Search behaviour

19.0

18.5

Training variables

Training incidence

54.3

Training duration

$1-16$ hours

6.7

10.0

$17-40$ hours

17.2

16.3

$41-80$ hours

11.1

9.5

$81-200$ hours

9.9

7.1

More than 200 hours

9.4

6.3

raining specificity

Overall general training

6.1

8.4

Management training

25.7

15.9

Specific training in own field

6.5

8.9

Specific training in other field

16.0

15.9

Training location

On-the-job training

12.0

10.8

Off-the-job training

42.3

38.3

Training payment

Entirely paid by employer

47.0

42.2

Partly paid by employer

Not paid by employer

Training time

5.5

4.8

Entirely during working hours

29.6

25.8

Partly during working hours

14.4

11.4

Not during working hours

10.2

11.9

raining objectives

Occupational updating

22.3

25.8

Career training

Retraining

Individual characteristics

Age (mean and s.d. in years)

$33.2(2.4)$

$32.5(2.3)$

Partner

Working partner

61.7

68.9

Non-working partner

15.2

3.1

No partner

23.1

28.0

Children

62.5

69.4

ducational level

No higher education

6.5

7.9

Higher vocational college

41.6

48.2

University

41.0

36.6 
Ph.D. or post university

Field of study

Science

Health

Economics and law

Social sciences

Education

Work experience (mean and s.d. in years)

Number of jobs since graduation (mean and s.d)

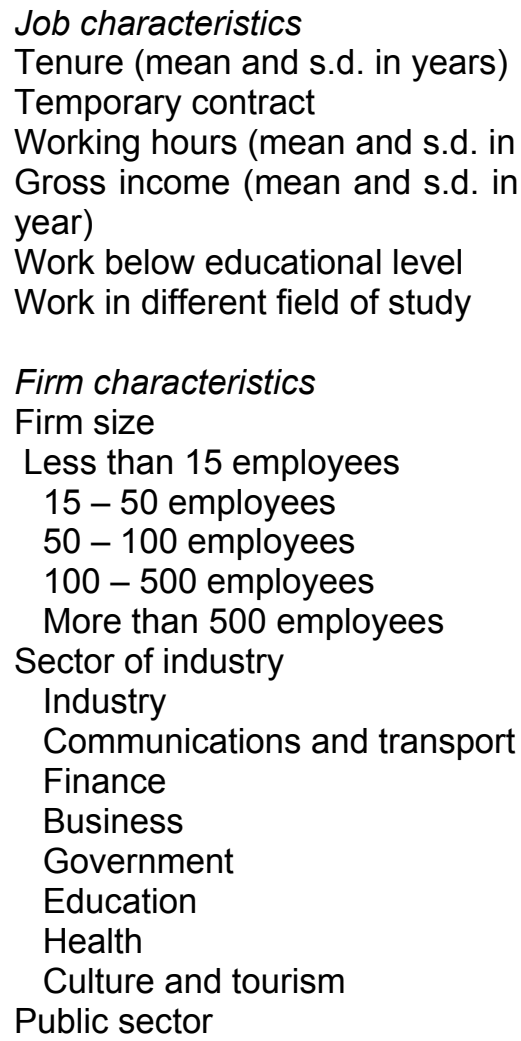

Firm characteristics

Firm size

Less than 15 employees

$15-50$ employees

$50-100$ employees

100 - 500 employees

More than 500 employees

Sector of industry

Industry

Communications and transport

Finance

Business

Government

Education

Health

Culture and tourism

Public sector

\section{8}

34.8

6.8

28.0

16.1

7.8

$5.9(2.0)$

$2.9(1.8)$

$3.0(2.5)$

10.9

$37.5(4.2)$

$71.7(21.1)$

19.2

11.1

10.5

$\begin{array}{ll}.4 .8 & 67.3\end{array}$

\section{Self-selection}

It should be noted that the relationship between training and turnover is more complex than the framework given so far. First of all, training is not followed at random. Participants are a selective group of employees who may have a higher probability of job search to begin with. For example, workers who are more able or more educated tend to receive more training (Altonji \& Spletzer, 1991; Green, 1993; Shields, 1998), but they also are more mobile (Carroll \& Mayer, 1986). At the firm level, selectivity occurs when firms offering training have a low personnel turnover because they tend to invest in other fields, such as management 
quality or employee relations, as well (cf. Zwick, 2002). Or, the other way around, when firms with a low training participation also have poor working conditions and, thus, a high turnover. Since characteristics associated with trainees, their jobs, and the firm they work in are important determinants of job search too, lack of control of these characteristics would lead to an upward bias in the estimates of training effects on job search. Therefore, I will include a number of individual characteristics (age, family status, education, work experience, and number of jobs since graduation), job characteristics (tenure, temporary contract, working hours, income, and education-job mismatches), and firm characteristics (firm size, sector of industry, and whether or not the firm belongs to the public sector) in the analyses. As Li et al. (2000) show, controlling for attributes like these can substantially reduce selection bias.

The descriptive statistics of these control variables can also be found in Table 2. The average age of the respondents is 33 years. Most of them have a (working) partner and children, although men more often have a non-working partner. Male respondents appear to be higher educated than female respondents: 41 per cent graduated from university and 11 per cent finished a Ph.D. or completed another type of post-doctoral education. For women, these percentages are 37 and 7 per cent respectively. Sex segregation in field of study (cf. Jacobs, 1996) is apparent: men specialise in science and economics/law, whereas women opt for health, social sciences, and education studies. On average, male respondents have 5.9 years of work experience since graduation, and female respondents 5.3 years; both have worked in approximately three jobs. The average tenure in the present job is about three years. Higher-educated women seem to hold somewhat less favourable jobs than highereducated men. They are more often employed in a job with a temporary contract (15 versus 11 per cent), on average work less hours per week (33 versus 37 working hours per week) and earn about 7,000 guilders ${ }^{11}$ less than men. The extent of education-job mismatches, however, is the same for men and women. One in five indicates to work in a job below their educational level, and one in ten in a job that requires a different field of study. With respect to firm characteristics, female respondents are more often employed in smaller firms than male respondents. The observed sex segregation in field of study is reflected in the sector of industry: men are more often employed in industry, finance, and business, whereas women more often work in health and education. Women also more often have a job in the public sector than men do (67 percent versus 45 per cent).

11. Measured as gross income per year when working full-time (40 hours a week). One Dutch guilder equals $€ 0.45$. 
However, controlling for observed self-selectivity may not be enough, since selectivity could also be based on heterogeneity that is unobserved (Heckman, Hotz, \& Dabos, 1987). Factors on which the researcher has no information, like aspirations, motivations, and ambitions, may influence both training participation and job search. I controlled for this unobserved heterogeneity by applying Heckman's two steps method (Heckman, 1979). ${ }^{12}$ For men, the results show that there is no significant self-selection present. For women, the same set of explanatory variables affects both training and search behaviour, which makes it impossible to adjust for self-selection. Based on these outcomes, I decided to estimate the effects of different aspects of training on job search using logistic regression analyses without specific controls for unobserved heterogeneity.

\section{Results}

First, I assess the estimates of each aspect of training in separate analyses of job search. Table 3 shows the results of these seven models for men and women separately. As mentioned, individual, job, and firm characteristics are included in these models as a control for self-selection. The results show that male workers who participate in training have a higher probability to search for a new job. This is not in line with the commitment perspective, which predicts a negative relationship between training incidence and job search. In addition, the human capital perspective hypothesis of no effect of training as such doesn't hold either. For female workers, training nevertheless has no significant impact on job search. The findings for training duration point in the same direction. The amount of hours spent in formal job training has no effect on women's job search behaviour, whereas men who participate longer in training (40 hours or more) are more likely to seek a new job than men who do not participate in training. However, this effect is not found for very long training courses of 200 hours or more.

12. In the first step, training is treated as endogenous. A selection equation is estimated with training being the dependent variable. The error terms generated in this equation are used to compute a correction variable (inverse of Mill's ratio). This correction variable is subsequently incorporated as a covariate in the second, substantial equation with job search behaviour as the dependent variable. The estimated effect of the correction variable indicates self-selection based on unobserved heterogeneity. Note that in order to obtain correct standard errors in the substantial equation, a correction procedure has to be applied. An important condition in Heckman's method is that the model has to be identifiable, which can be achieved by incorporating at least one variable in the first analysis that is absent in the second one. It turns out that for men, three variables have a significant impact on training, and at the same time do not affect job search behaviour: (1) their educational level before entering tertiary education, (2) their opinion on "skills I learned during my education are sufficient to start working in my own field of study", and (3) their opinion on "skills I learned during my education are sufficient to learn additional skills at work". Incorporating these variables in the first analysis, and using this information in the second analysis on job search, shows that there is no significant self-selection for men: the estimated effect of the correction variable is -.491 with a standard error of .719 . 
Table 3

Estimates of separate logistic regression analyses of several aspects of formal job training ${ }^{a}$ on job search behaviour for men and women, with control variables ${ }^{b}$
Men $(n=658)$
(s.e.)
Women $(n=621)$
B
B
(s.e.)

Model A: Training incidence

Training

Model B: Training duration

$1-16$ hours

$17-40$ hours

$41-80$ hours

$81-200$ hours

More than 200 hours

Model C: Training specificity

Overall general training

Management training

Specific training in own field

Specific training in other field

Model D: Training location

On-the-job training

Off-the-job training

Model E: Training payment

Entirely paid by employer

Partly paid by employer

Not paid by employer

Model F: Training time

Entirely during working hours

Partly during working hours

Not during working hours

Model G: Training objectives

Occupational updating

Career training

Retraining

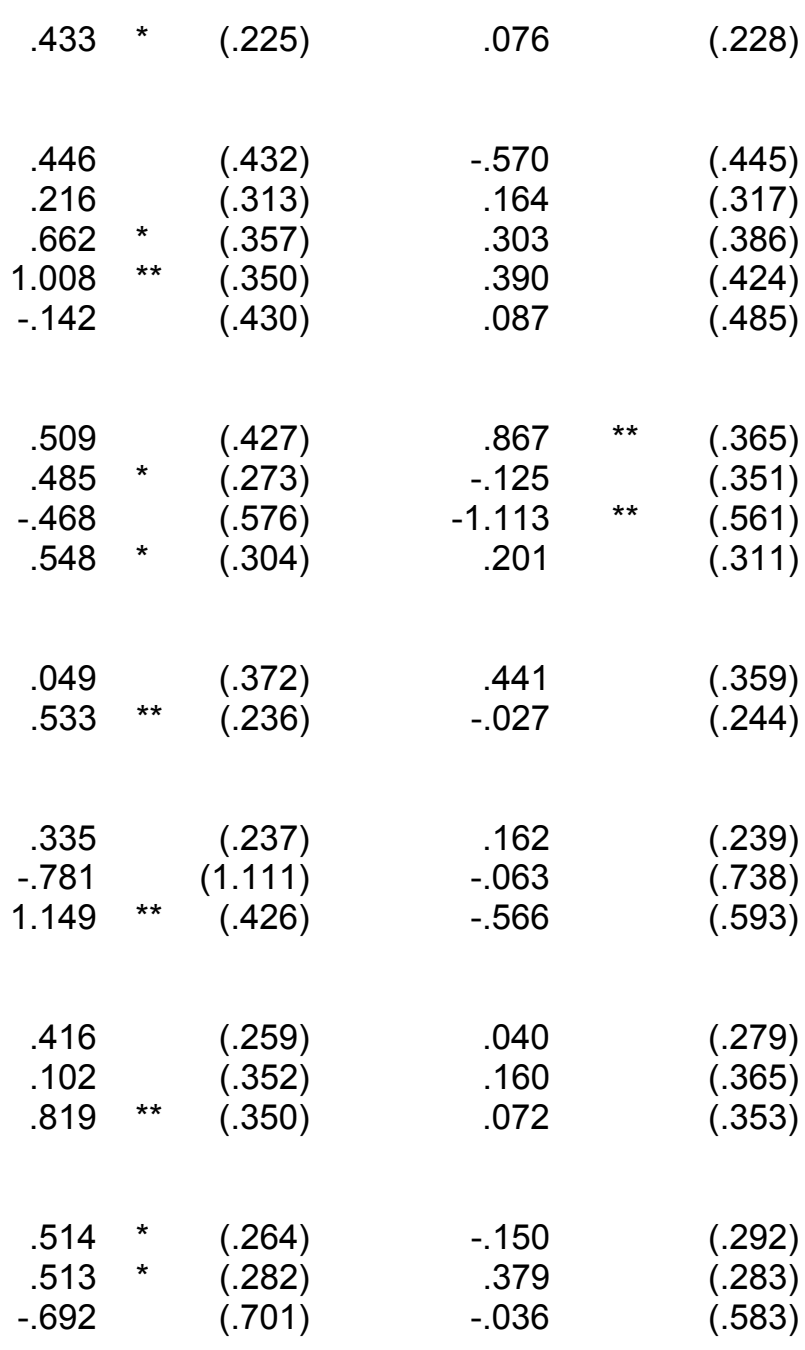

${ }^{*} p<0.100 ;{ }^{* *} p<0.050 ;{ }^{* * *} p<0.010$

a The reference category is no training.

b Controls include individual characteristics (age, partner, children, educational level, field of study, work experience, number of jobs since graduation), job characteristics (tenure, temporary job, working hours, gross income, work below educational level, work in different field of study), and firm characteristics (firm size, sector of industry, public sector).

With respect to the specificity of training, the human capital perspective predicts negative effects of specific training on job search. Specific training in one' own field of study indeed decreases the probability to search for a new job, although this effect is not significant for male workers. Specific training in another field, however, leads to more job search, especially for men. The hypotheses of the commitment perspective regarding general training are not corroborated either. Management training does not decrease the probability 
of job search: This effect is not significant for women. In addition, men who participate in management training are even more likely to search for a new job. The same holds for female workers who follow overall general training. Moreover, workers who follow on-the-job training do not display more job search behaviour than workers who are not trained at all, as the human capital perspective predicts. In fact, off-the-job training increases men's likelihood to look for a new job. This also is not in line with the commitment perspective, which predicts a negative effect of off-the-job training on job search behaviour. For women, such an effect appears to be non-significant.

Both training costs and training time do not have an impact on women's job search behaviour. For male workers, significant effects are found, but these are in conflict with the hypotheses of both the human capital perspective and the commitment perspective. Training paid by the employer, or training followed during working hours, does not decrease the probability to search for a new job. On the contrary, training not paid for by the employer and which is followed during leisure time induces more job search for men.

Finally, we take a look at the objectives of training. Men who participate in occupational updating or career training are more likely to look for a new job than men who do not participate in training. This is not in line with the hypotheses of the human capital perspective or the commitment perspective. Retraining induces a lower probability to search for another job, but this effect is not significant. Moreover, the effects of training objectives on women's job search behaviour are insignificant as well.

To sum up, I find little support for either the human capital perspective or the commitment perspective. Although specific training in one's own field of study decreases the probability to search for a new job, at least for female employees, on the whole, the findings appear to be either not significant or not in line with the hypotheses. In fact, general training seems to induce more job search behaviour, as the results of overall general training for women and of management training for men show. In addition, men participating in off-the-job training and in career training are more likely to search for a new job. On the other hand, I observe that training which can perceived as being not a gift by the employer, like training not paid by the employer or training followed during leisure time, increases the probability to search for another job. This could be interpreted as a negative version of the commitment perspective: Training provided by the employer does not affect turnover, but when the direct and indirect costs of training have to be paid by the employees themselves, they are more inclined to start looking for a new job. However, before reaching conclusions, it is important to incorporate all aspects of training in one model simultaneously. Only in this way, the predictions of the two hypotheses can properly be tested.

\section{Results of Simultaneous Model}

Table 4 shows the results of logistic regression analyses including all mentioned aspects of formal job training simultaneously. Again, I estimate the effects of training on job search behaviour for men and women separately, controlling for individual, job, and firm characteristics. It turns out that training incidence and training duration do not have a 
significant impact on men's job search anymore. For women, the effect of training incidence - though negative - is insignificant as well. Training duration, however, has a positive influence on women's job search behaviour when including all aspects of training in the analyses simultaneously. Female workers who follow 40 to 200 hours of training are more likely to search for a new job. Again, this is not in line with the hypotheses of the human capital perspective or the commitment perspective.

Table 4

Estimates of logistic regression analyses of several aspects of formal job training on job search behaviour for men and women

$$
\begin{array}{lll}
\text { Men }(n=658) & \text { Women }(n=621) \\
\text { (s.e. }) & \text { B } & \text { (s.e. })
\end{array}
$$

\begin{tabular}{|c|c|c|c|c|}
\hline $\begin{array}{l}\text { Training variables } \\
\text { Training incidence }\end{array}$ & & & & (091) \\
\hline \multicolumn{5}{|l|}{ Training duration } \\
\hline $1-16$ hours (ref.) & - & $(-)$ & - & $(-$ \\
\hline $17-40$ hours & -.180 & $(.507)$ & .758 & $(.524)$ \\
\hline $41-80$ hours & .277 & $(.528)$ & $1.198^{\star *}$ & $(.585)$ \\
\hline $81-200$ hours & .648 & $(.549)$ & $1.292^{* *}$ & (.611) \\
\hline More than 200 hours & -.356 & $(.627)$ & 1.000 & $(.694)$ \\
\hline \multicolumn{5}{|l|}{ Training specificity } \\
\hline Overall general training & -.079 & $(.518)$ & .663 & $(.466)$ \\
\hline Management training & -.035 & $(.350)$ & -.572 & $(.446)$ \\
\hline Specific training in own field & $-1.050^{*}$ & $(.616)$ & $-1.464^{* *}$ & $(.620)$ \\
\hline Specific training in other field (ref.) & - & $(-)^{\prime}$ & - & $(-)^{\prime}$ \\
\hline \multicolumn{5}{|l|}{ Training location } \\
\hline On-the-job training & -.269 & $(.397)$ & .435 & $(.399)$ \\
\hline Off-the-job training (ref.) & & $(-)^{\prime}$ & 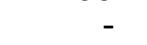 & $(-)$ \\
\hline \multicolumn{5}{|l|}{ Training payment } \\
\hline Entirely paid by employer & $-1.046^{*}$ & $(.538)$ & 1.055 & $(.705)$ \\
\hline Partly paid by employer & -1.992 & $(1.236)$ & .722 & $(.986)$ \\
\hline Not paid by employer (ref.) & & $(-)^{\prime}$ & & \\
\hline \multicolumn{5}{|l|}{ Training time } \\
\hline Entirely during working hours & -.130 & $(.428)$ & -.320 & $(.453)$ \\
\hline Partly during working hours & -.647 & $(.477)$ & -.078 & $(.498)$ \\
\hline Not during working hours (ref.) & - & $(-)^{\prime}$ & - & $(-)^{\prime}$ \\
\hline \multicolumn{5}{|l|}{ Training objectives } \\
\hline Occupational updating & $1.526^{*}$ & $(.829)$ & .063 & $(.674)$ \\
\hline Career training & $1.672^{* *}$ & $(.846)$ & .375 & $(.667)$ \\
\hline Retraining (ref.) & - & $(-)$ & - & \\
\hline \multicolumn{5}{|l|}{ Individual characteristics } \\
\hline Age & .110 & $(.050)$ & .076 & $(.053)$ \\
\hline \multicolumn{5}{|l|}{ Partner } \\
\hline Working partner & -.086 & $(.299)$ & -.200 & $(.272)$ \\
\hline Non-working partner & -.299 & $(.437)$ & $1.089^{*}$ & $(.572)$ \\
\hline No partner (ref.) & - & $(-)$ & - & $(-)$ \\
\hline \multicolumn{5}{|l|}{ Field of study } \\
\hline Science & -.265 & $(.511)$ & .018 & $(.588)$ \\
\hline Health & $-1.508^{*}$ & $(.852)$ & -.453 & (.653) \\
\hline Economics and law & .405 & $(.507)$ & -.388 & $(.731)$ \\
\hline Social Sciences & -.066 & $(.539)$ & .121 & i \\
\hline Education (ref.) & . & $(-)^{\prime}$ & - & $(-$ \\
\hline
\end{tabular}


Table 4 (continued)

Estimates of logistic regression analyses of several aspects of formal job training on job search behaviour for men and women

$$
\begin{array}{ll}
\text { Men }(n=658) & \text { Women }(\mathrm{n}=621) \\
\text { (s.e. }) & \text { B }
\end{array}
$$

\begin{tabular}{|c|c|c|c|c|}
\hline $\begin{array}{l}\text { Work experience } \\
\text { Work experience squared } \\
\text { Number of jobs since graduation }\end{array}$ & $\begin{array}{l}.041 \\
.007 \\
.010\end{array}$ & $\begin{array}{l}(.272) \\
(.024) \\
(.070)\end{array}$ & $\begin{array}{l}-.390^{*} \\
.041^{*} \\
.021\end{array}$ & $\begin{array}{l}(.213) \\
(.021) \\
(.072)\end{array}$ \\
\hline $\begin{array}{l}\text { Job characteristics } \\
\text { Tenure } \\
\text { Tenure squared } \\
\text { Temporary contract } \\
\text { Working hours } \\
\text { Gross income } \\
\text { Work below educational level } \\
\text { Work in different field of study }\end{array}$ & $\begin{array}{l}.331^{*} \\
-.042^{*} \\
.726^{*} \\
-.040 \\
-.013^{*} \\
.373 \\
.618^{*}\end{array}$ & $\begin{array}{l}(.172) \\
(.022) \\
(.387) \\
(.028) \\
(.007) \\
(.309) \\
(.331)\end{array}$ & $\begin{array}{l}.140 \\
-.022 \\
.753^{* *} \\
-.033 \\
-.005 \\
.228 \\
-.645\end{array}$ & $\begin{array}{l}(.186) \\
(.022) \\
(.345) \\
(.022) \\
(.008) \\
(.334) \\
(.449)\end{array}$ \\
\hline $\begin{array}{l}\text { Firm characteristics } \\
\text { Firm size } \\
\text { Less than } 15 \text { employees } \\
15-50 \text { employees } \\
50-100 \text { employees } \\
100-500 \text { employees } \\
\text { More than } 500 \text { employees (ref.) }\end{array}$ & $\begin{array}{c}-.771^{*} \\
-.533 \\
-.502 \\
-.316 \\
-\end{array}$ & $\begin{array}{c}(.427) \\
(.375) \\
(.415) \\
(.340) \\
(-)\end{array}$ & $\begin{array}{r}.252 \\
.479 \\
.304 \\
.348 \\
-\end{array}$ & $\begin{array}{r}(.524) \\
(.490) \\
(.528) \\
(.493) \\
(-)\end{array}$ \\
\hline $\begin{array}{l}\text { Sector of industry } \\
\text { Industry (ref.) } \\
\text { Communications and transport } \\
\text { Finance } \\
\text { Business } \\
\text { Government } \\
\text { Education } \\
\text { Health } \\
\text { Culture and tourism } \\
\text { Public sector }\end{array}$ & $\begin{array}{r}-.426 \\
-.585 \\
-.097 \\
-.066 \\
-.173 \\
.067 \\
.634 \\
-.044\end{array}$ & $\begin{array}{l}(-) \\
(.651) \\
(.581) \\
(.337) \\
(.569) \\
(.526) \\
(.569) \\
(.557) \\
(.323)\end{array}$ & $\begin{array}{l}. \\
.133 \\
-.724 \\
.612 \\
.149 \\
.583 \\
.617 \\
1.179^{\star} \\
-.124\end{array}$ & $\begin{array}{l}(-) \\
(.750) \\
(.948) \\
(.539) \\
(.691) \\
(.672) \\
(.624) \\
(.680) \\
(.324)\end{array}$ \\
\hline Nagelkerke $\mathrm{R}^{2}$ & \multicolumn{2}{|c|}{.186} & \multicolumn{2}{|c|}{.159} \\
\hline
\end{tabular}

${ }^{*} p<0.100 ;{ }^{* *} p<0.050 ;{ }^{* * *} p<0.010$

Specific training in one's own field of study negatively affects male and female employees' job search, whereas general training does not have a significant impact. This is exactly what the human capital perspective predicts. However, training location, costs, and time no longer affect job search behaviour. This shows that is important to include many aspects of training in one model. After controlling for training specificity, the effects of on-the-job versus off-thejob training, training paid for by the employer versus self-financed training, and training followed during working hours versus training followed during leisure time are not significant anymore. There is one exception: training entirely paid for by the employer reduces men's probability to look for another job. This is in line with both the human capital perspective and the commitment perspective. Finally, training objective is important for male workers' job search behaviour. Men who participate in occupational updating or career training are more likely to search for a new job. Training objectives do not affect women's job search, however.

To complete the picture, I briefly discuss the estimates of the control variables shown in Table 4. Most of the findings observed here are in line with previous research on employees' 18 
job search and mobility patterns. For example, having a temporary contract induces more job search than having a permanent contract. Again, large differences for men and women are found. For men, age, tenure, and working in a different field of study positively influence their job search behaviour. Male workers who have an educational background in health studies, who earn less, and who work in a small firm have a lower probability to search for a new job. Women, on the other hand, are more inclined to look for another job when their partner is not working, or when they are working in culture and tourism. Work experience decreases women's job search behaviour, although this effect declines with the number of experience years.

\section{Conclusions and Discussion}

This study examines the impact of formal training on young men's and women's job search behaviour. It advances on previous research on the relationship between training and turnover in two important ways. First, the insights of the well-studied economic human capital perspective are contrasted with the insights of a less widespread perspective mostly found in psychological and HRM literature: the commitment perspective. Second, instead of studying one aspect of training only, this study incorporates several aspects of formal training in one model and looks at training incidence, duration, specificity, location, costs, time, and objectives simultaneously. The theoretical part of the study makes clear that different hypotheses on the impact of these training aspects can be derived from the human capital perspective and the commitment perspective. In short, the human capital perspective distinguishes between general and specific training and states that specific training will lead to less turnover, whereas general training will not clearly affect job search. The commitment perspective, on the other hand, stresses the importance of training in generating organisational commitment. Training that is more perceived as a gift will increase employees' commitment and thus lead to less job search behaviour.

Which of the two perspectives is the most promising in explaining the relationship between training and turnover? When studying each aspect of training separately, I find that specific training decreases the probability to search for a new job for women. This is in line with the hypothesis of the human capital perspective. However, two other conclusions are prominent as well. First, training not paid for by the employer and training followed during leisure time appear to increase men's job search behaviour. As mentioned before, this could be interpreted as a negative version of the commitment perspective: Training that is perceived as not being a gift (e.g. when the employee bears the direct and indirect training costs) leads to more job search. Second, general training (like overall general training for women and management and off-the-job training for men) seems to induce more job search behaviour. This is not in line with either the human capital perspective or the commitment perspective. When incorporating all aspects of training in one model simultaneously, the negative effect of specific training in one's own field of study stays. The other findings, however, present less support for the human capital perspective or the commitment perspective. For example, I observe that women who participate longer in training are more likely to search for a new job, while the same holds for men who follow occupational updating or career training. 
Moreover, other aspects of training do not significantly affect job search. These results first of all show that it is important to examine more than one aspect of training before reaching conclusions. After including training specificity in the model, training location, costs, and time no longer influence employees' job search behaviour. Moreover, it seems that both the human capital perspective and the commitment perspective are not very successful in predicting the relationship between training participation and turnover. One possible explanation might be that training not only induces more job search, but that job search may also bring about more training. Workers who intent to quit will invest in human capital to improve their position on the labour market (Zweimüller \& Winter-Ebmer, 2000). This means that training is not a cause, but a prerequisite for job search. It would be interesting if future research could in some way unravel this issue of reverse causation, although this will not be easy. Measuring training variables in a period before the job search takes place (e.g. by using longitudinal or panel data) probably will not solve the problem, since sequence in time is not the same as causality (cf. Goldthorpe, 2001). Perhaps more information about workers' motives to follow training might help in opening this black box.

More information on workers' training motives is important in another way as well. It provides a stricter test of the commitment perspective, since voluntary training could be perceived more as a gift than obligatory training (e.g. training due to employers' certification standards or collective bargaining agreements). Having more insights into workers' motives - do they want to follow training or do they have to - could, thus, improve our understanding of the relationship between training and turnover. Studying workers' motives might even be more important when the focus is not on higher-educated workers, but on their lower-educated counterparts, for the concept of organisational commitment might hold more for the latter group. A related point worth investigating is explicit training contracts that exist between employers and employees. Pay-back clauses might influence the relation between training participation and turnover, as they encourage the employer to pay for the training while imposing a penalty on employees who quit within a certain period. In doing so, they reduce the risk of trained workers leaving the firm (Brunello \& De Paola, 2004).

Finally, another interesting theme for future research would be to explore gender variation in the relationship between training and turnover. This study shows that there are major differences in the impact of formal training on job search between male and female workers. It would be tempting to reveal the mechanisms that underlie these differences. For example, gender dissimilarities in family obligations and career opportunities might play a role. In this respect, it would be equally important to pay more attention to possible trends in the relationship between training and turnover over time. 


\section{References}

Acemoglu, Daron and Jörn-Steffen Pischke (1999). "The Structure of Wages and Investment in General Training." The Journal of Political Economy, 107 (3): 539-572.

Altonji, Joseph G. and Jamers R. Spletzer (1991). "Worker Characteristics, Job Characteristics and the Receipt of On-the-Job Training." Industrial and Labour Relations Review, 45 (1): 58-79.

Arulampalam, Wiji and Alison L. Booth (1998). "Training and Labour Market Flexibility: Is There a Trade-Off?" British Journal of Industrial Relations, 36 (4): 521-536.

Barrett, Alan and Philip J. O'Connell (2001). "Does Training Generally Work? Measuring the Returns to In-Company Training." Industrial and Labor Relations Review, 54 (3): 647-662.

Bartel, Ann P. (1995). "Training, Wage Growth and Job Performance: Evidence from a Company Database." Journal of Labor Economics, 13 (3): 401-425.

Becker, Gary S. (1962). "Investment in Human Capital: a Theoretical Analysis." Journal of Political Economy, 70 (5): 9-49.

Bennett, Robert, Howard Glennerster and Douglas Nevison (1992). "Investing in Skill: To Stay on or Not to Stay on?" Oxford Review of Economic Policy, 8 (2): 130-145.

Bishop, John .H. (1997). "What We Know About Employer-Provided Training; A Review of the Literature." Research in Labor Economics, 16: 19-87.

Booth, Alison L. (1991). "Job-related Formal Training; Who Receives It and What is It Worth?" Oxford Bulletin of Economics and Statistics, 53 (3): 281-294.

Brunello, Giorgo and Maria De Paola (2004). Market Failures and the Under-Provision of Training. CESifo Working Paper no. 1286. Munich: CESifo.

Carroll, Glenn R. and Karl Ulrich Mayer (1986). "Job-Shift Patterns in the Federal Republic Of Germany: The Effects of Social Class, Industrial Sector, and Organizational Size." American Sociological Review, 51 (3): 323-341.

De Graaf, Paul M. and Ruud Luijkx (1997). Structurele veranderingen, aspiraties en arbeidsmobiliteit [Structural Changes, Aspirations, and Labour Mobility]. OSA-werkdocument W155. Tilburg: OSA.

De Grip, Andries, Hans Heijke and Ed Willems (1998). "Training and Mobility." The Netherlands' Journal of Social Sciences, 34 (1): 78-98.

Dekker, Ron, Andries de Grip and Hans Heijke (2002). "The Effects of Training and Overeducation on Career Mobility in a Segmented Labour Market." International Journal of Manpower, 23 (2): 106125.

De Wolff, Charlotte, Ruud Luijkx and Marcel Kerkhofs (2003). "Wie wat leert is weg - of niet? De effecten van bedrijfsscholing op functie- en baanverandering. [Who learns quits - or not? The Effects of Company Training on Job Change]" Tijdschrift voor Arbeidsvraagstukken, 19 (2): 131141.

Dolton, Peter J. and Michael P. Kidd (1998). “Job Changes, Occupational Mobility and Human Capital Acquisition: An Empirical Analysis.” Bulletin of Economic Research, 50 (4): 265-295.

Eckaus, R.S. (1963). "Investment in Human Capital: A Comment." The Journal of Political Economy, 71 (5): 501-504.

Elias, Peter (1994). "Job-Related Training, Trade Union Membership, and Labour Mobility: A Longitudinal Study." Oxford Economic Papers, 46 (4): 563-578. 
Fevre, Ralph, Gareth Rees and Stephen Gorard (1999). "Some Sociological Alternatives to Human Capital Theory and their Implications for Research on Post-compulsory Education and Training." Journal of Education and Work, 12 (2): 117-140.

Form, William (1992). "Self-Employed Manual Workers: Petty Bourgeoisie or Working Class?" Social Forces, 60 (4): 1050-1069.

Freeman, Richard B. (1998). "War of the Models: Which Labour Market Institutions for the 21st Century?" Labour Economics, 5 (1): 1-24.

Goldthorpe, John H. (2001). "Causation, Statistics, and Sociology." European Sociological Review, 17 (1): 1-20.

Green, Francis (1993). "The Determinants of Training of Male and Female Employees in Britain." Oxford Bulletin of Economics and Statistics, 55 (1): 103-122.

Green, Francis, Alan Felstead, Ken Mayhew and Alan Pack (2000). "The Impact of Training on Labour Mobility: Individual and Firm-Level Evidence from Britain." British Journal of Industrial Relations, 38 (2): 261-275.

Gritz, R. Mark (1993). "The Impact of Training on the Frequency and Duration of Employment." Journal of Econometrics, 57 (1): 21-51.

Groot, Wim and Henriëtte Maassen van den Brink (2000). "Education, Training and Employability." Applied Economics, 32 (5): 573-581.

Heckman, James J. (1979). "Sample Selection Bias as Specification Error." Econometrica, 47 (1): 153-161.

Heckman, James J., V. Joseph Hotz and Marcelo Dabos (1987). "Do We Need Experimental Data to Evaluate the Impact of Manpower Training on Earnings?" Evaluations Review, 11 (4): 395-427.

Heyes, Jason and Mark Stuart (1996). "Does Training Matter? Employee Experiences and Attitudes." Human Resource Management Journal, 6 (3); 7-21.

Jacobs, Jerry A. (1996). "Gender Inequality and Higher Education." Annual Review of Sociology, 22: 153-185.

Katz, Eliakim and Adrian Ziderman (1990). "Investment in General Training: The Role of Information and Labour Mobility." The Economic Journal, 100 (403): 1147-1158.

Krueger, Alan and Cecilia Rouse (1998). "The Effect of Workplace Education on Earnings, Turnover and Job Performance." Journal of Labour Economics, 16 (1): 61-94.

Lazear, Edward (2003). Firm-Specific Human Capital: A Skill-Weights Approach. NBER Working Paper No. 9679. Cambridge, MA: NBER.

Li, Jiang Hong, Markus König, Marlis Buchmann, and Stefan Sacchi (2000). "The Influence of Further Education on Occupational Mobility in Switzerland." European Sociological Review, 16 (1): 43-65.

Loewenstein, Mark A. and James R. Spletzer (1997). "Delayed Formal On-The-Job Training." Industrial and Labor Relations Review, 51 (1):82-99.

Loewenstein, Mark A. and James R. Spletzer (1999). "General and Specific Training. Evidence and Implications." The Journal of Human Resources, 34 (4): 710-733.

Lynch, Lisa M. (1991). "The Role of Off-the-Job vs. On-the-Job Training for the Mobility of Women Workers." American Economic Review, Papers and Proceedings, 81 (2): 151-156.

Lynch, Lisa M. (1992a). "Private-Sector Training and the Earnings of Young Workers." American Economic Review 82 (1): 299-312. 
Lynch, Lisa M. (1992b). Differential Effects of Post-School Training on Early Career Mobility. Cambridge, Mass: National Bureau of Economic Research Working Paper, no 4034.

Lynch, Lisa M. (1993). "Entry-Level Jobs: First Rung on the Employment Ladder or Economic Dead End?" Journal of Labor Research, 14 (3): 249-263.

Lynch, Lisa M. and Sandra E. Black (1998). "Beyond the Incidence of Employer-Provided Training." Industrial and Labor Relations Review, 52 (1): 64-81.

Mincer, Jacob (1962). "On-the-Job Training: Costs, Returns and Some Implications." The Journal of Political Economy, 70 (5): 50-79.

Noe, Raymond A. and Steffanie L. Wilk (1993). "Investigation of the Factors that Influence Employees' Participation in Development Activities." Journal of Applied Psychology, 78 (2): 291302.

Parent, Daniel (1999). "Wages and Mobility: The Impact of Employer-Provided Training." Journal of Labor Economics, 17 (2): 298-317.

Rosenfeld, Rachel A. (1992). "Job Mobility and Career Processes." Annual Review of Sociology, 18: $39-62$.

Royalty, Anne Beeson (1996). "The Effects of Job Turnover on the Training of Men and Women." Industrial and Labour Relations Review, 49 (3): 506-521.

Shields, Michael (1998). "Changes in the Determinants of Employer-Funded Training For Full-Time Employees in Britain, 1984-1994." Oxford Bulletin of Economics and Statistics, 60 (2): 189-214.

Smith, Andrew and Geoff Hayton (1999). "What Drives Enterprise Training? Evidence from Australia." The International Journal of Human Resource Management, 10 (2): 251-272.

Stevens, Margaret (1999). "Human Capital Theory and UK Vocational Training Policy." Oxford Review of Economic Policy, 15 (1): 16-32.

Stromback, Thorsten (2002). Training and Mobility. Paper presented at a seminar for the Labour Economics Group at Oxford University, March 2002, Oxford.

Tannenbaum, Scott I., John E. Mathieu, Eduardo Salas and Janis A. Cannon-Bowers (1991). "Meeting trainees' expectations: The Influence of Training Fulfilment on the Development of Commitment, Self-Efficacy, and Motivation." Journal of Applied Psychology, 76, 759-769.

Veum, Jonathan R. (1995). "Sources of Training and Their Impact on Wages." Industrial and Labor Relations Review, 48 (4): 812-826.

Veum, Jonathan R. (1997). "Training and Job Mobility among Young Workers in the US." Journal of Population Economics, 10 (2): 219-234.

Weisberg, Jacob and Alan Kirschenbaum (1991). "Employee Turnover Intentions: Implications From a National Sample." The International Journal of Human Resource Management, 2 (3): 359-375.

Wholey, Douglas R. (1990). "The Effects of Formal and Informal Training on Tenure and Mobility in Manufacturing Firms." The Sociological Quarterly, 31 (1): 37-57.

Wolf, Wendy C. and Rachel Rosenfeld (1978). "Sex Structure of Occupations and Job Mobility." Social Forces, 56 (3): 823-844.

Zweimüller, Josef and Rudolf Winter-Ebmer (2000). Firm-specific Training: Consequences for Job Mobility, IZA Discussion Paper no. 138.

Zwick, Thomas (2002). Continuous Training and Firm Productivity in Germany. ZEW Discussion Paper no. 02-50. 